\section{Club of Rome associations}

\section{David Spurgeon, Ottawa}

CANADA is the latest country to have formed a national association inspired by the Club of Rome. The decision was made at a meeting in Toronto early in May, and the venture has the backing of an impressive array of government and business officials.

The association's objects are "to promote study and discussion among all segments of the Canadian public of the nature of world problems and the need to develop new policies, attitudes and courses of action to ensure a stable and viable future for mankind

More specifically, it will attempt to identify Canada's role in the solution of world problems, and the implications for Canada of possible world solutions.

Both the co-founders of the Club of Rome, Dr Aurelio Peccei of Italy and Dr Alexander King, who until recently was with the OECD in Paris, attended the Toronto meeting, which was opened with a welcoming letter from Canada's Prime Minister, Pierre Trudeau. From their accounts it was apparent that the club-largely through the impact of the MIT study it sponsored, The Limits of Growth-had made considerable progress in directing attention to world problems since its inception in 1968.

One reason for thinking so, as suggested by Dr Peccei, is the establishment of a series of United Nations Conferences for discussion of world problems such as population, food, energy and materials. Another is the organisation in many nations of groups like the Club of Rome.

As described by Dr King, these included a whole diversity of approaches. The first was set up in Holland, which according to King is not surprising, because of its twin problems of dense population and heavy industrialisation. The Dutch association is a group of private people gathered in a nonparty organisation.

The second-also not surprisingly, for the same reasons-was organised in Japan, on a different basis, backed by and formed as a committee of the techno-economic society. Groups in other countries include some not connected with the Club of Rome but interested in similar problems (for example, Great Britain and Austria), and luncheon clubs and groups of engineers or teachers in France, Denmark, Belgium and Sweden.

Finland has formed a more formal study group to determine what the role should be of a small, progressive country in the modern world; Switzerland, with four Club members, invited four government members to discuss

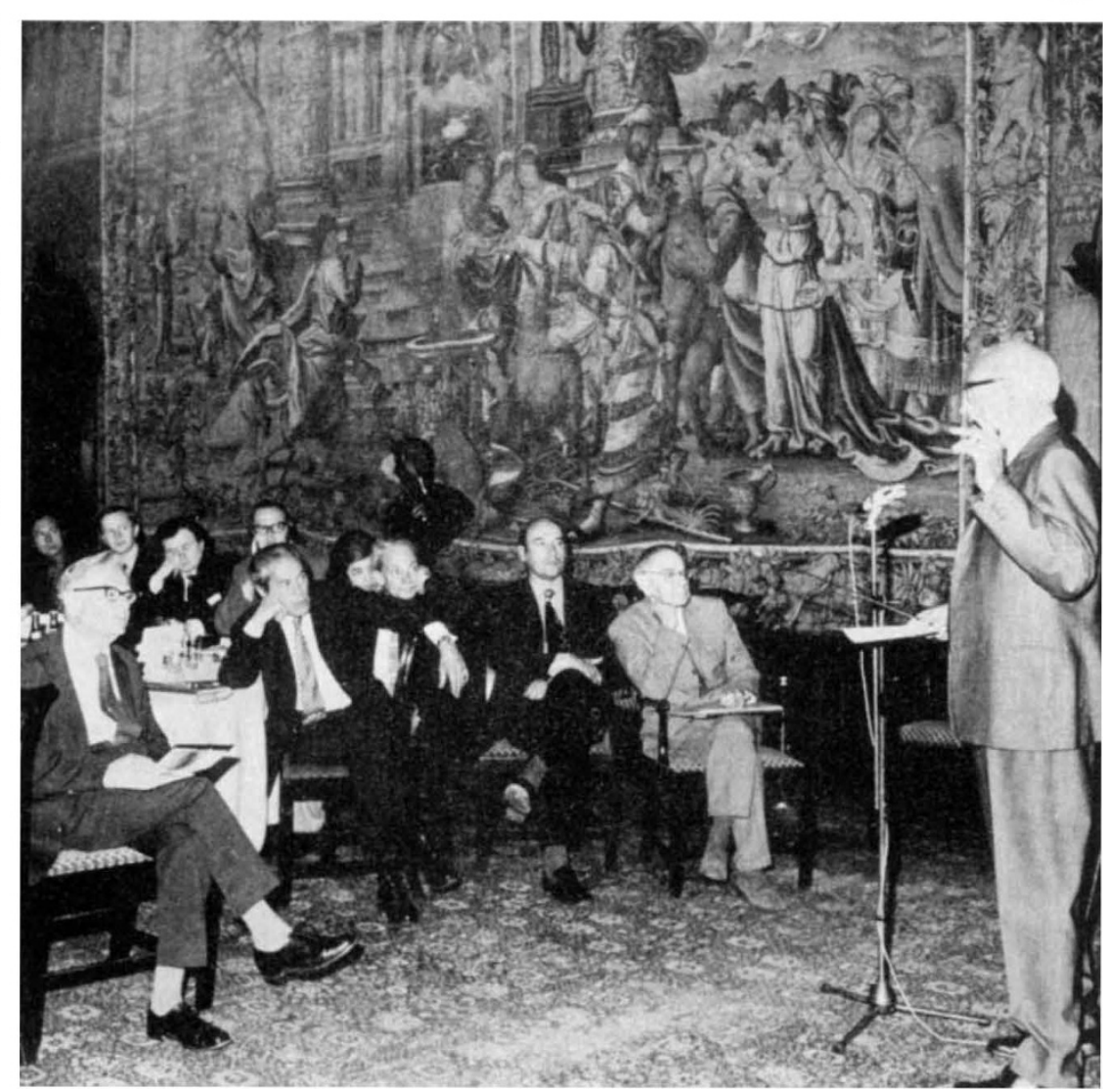

BENEATH the elegant tapestries of new ideas. All seemed agreed that the Schlosshotel, Kronberg, Germany breaking out from conventional thinka small group of biologists, philoso- ing was a major ingredient in creativity phers and psychiatrists gathered re- - the agreement was so complete that cently to constitute the Boehringer it must qualify as conventional thinkIngelheim Symposium on the Creative ing and therefore... Monod discussed Process in Science and Medicine. 'subjective simulation'-a process Pictured above, listening to Sir John almost of putting yourself in the posiEccles testify are, in the front row, tion of the electron or whatever that Sir Hans Krebs, Jacques Monod, you are thinking about. The debt of Manfred Eigen, Desmond Morris and many participants to Popper was Sir Karl Popper. What leads to some clearly great-an interesting contrast scientists being creative way above the with the world of physical science average, and does the creativity of where one's impression is that there is scientists bear any resemblance to that less understanding of what he is about. of artists and composers? Participants Desmond Morris had probably were decidedly coy about speaking the nicest story to tell-A journother than in the abstract, despite alist once asked Picasso: What is Krebs's personal example of trying to creativity? 'I don't know, and if I did piece together how he came to produce I wouldn't tell you.'
Club of Rome thinking and found them receptive to the points where they decided that both the traditional political organisation and neutrality of the country was obsolete.

But Dr King found some of the keenest interest in an unexpected place: South Africa. I was in South Africa recently, he said, "and, much to my surprise, found the Club of Rome better known in that country than in any other." Some citizens there have formed an independent information group who just meet and talk.

The Canadian Association for the Club of Rome has applied for a charter as a corporation without share capital. Its first directors include the president of the pulp and paper industry's research institute, Dr Pierre R. Gendron; Senator Maurice Lamontagne, whose senate committee carried out one of the most comprehensive studies of national science policy yet made; a retired oil company executive, Mr Ronald Ritchie; the president of the Ontario Research Foundation, Dr William Stadelman; the former Chief Science Adviser to the Federal Cabinet, now Dean of Applied Sciences at Queen's University, Dr Robert J. Uffen: and a senior civil servant with many years experience in Canadian Science policy, Dr J. Rennie Whitehead. 